\title{
BAP1-related tumor predisposition syndrome
}

INSERM

\section{Source}

INSERM. (1999). Orphanet: an online rare disease and orphan drug data base. BAP1related tumor predisposition syndrome. ORPHA:289539

BAP1-related tumor predisposition syndrome (TPDS) is an inherited cancer-predisposing syndrome, associated with germline mutations in BAP1 tumor suppressor gene. The most commonly observed cancer types include uveal melanoma, malignant mesothelioma, renal cell carcinoma, lung, ovarian, pancreatic, breast cancer and meningioma, with variable age of onset. Common cutaneous manifestations include malignant melanoma, basal cell carcinoma and benign melanocytic BAP1-mutated atypical intradermal tumors (MBAIT) presenting as multiple skin-coloured to reddishbrown dome-shaped to pedunculated, well-circumscribed papules with an average size of $5 \mathrm{~mm}$, histologically predominantly composed of epithelioid melanocytes with abundant amphophilic cytoplasm, prominent nucleoli and large, vesicular nuclei that vary substantially in size and shape. 